${ }^{1}$ University of Ljubljana,

\title{
THE IMPORTANCE OF SYSTEMS FOR CONTROLLING LOGISTICS COSTS IN THE SUPPLY CHAIN: A CASE STUDY FROM THE SLOVENIAN AUTOMOTIVE INDUSTRY
}

\begin{abstract}
Participating in the automotive industry brings new responsibilities for suppliers who, in order to meet customer demands, must strive towards improving business processes, while at the same time reducing costs. These demands can disrupt the operations of companies that do not have a system for controlling logistics costs. On the other hand, customer demands can be the cause of other types of disruptions in companies that have such a system in place, stemming from an excessive focus on cost reduction. To tackle this problem, a survey was conducted on a sample of 30 Slovenian companies that operate as suppliers in the automotive industry. Its objective was to determine how different customer demands along the supply chain can affect the business processes of suppliers and the level of logistics costs. The survey revealed that companies that use a system for controlling logistics costs experience fewer disruptions in their business processes in their efforts to satisfy customer demands. These companies also display a higher level of integration of business processes and use a different approach when dealing with the various participants of the supply chain. The survey also sets clear participation guidelines for suppliers in the supply chain of the automotive industry and points out how companies can benefit from using a system for controlling logistics costs in other ways, aside from the cost controlling aspect.
\end{abstract}

\section{KEY WORDS}

logistics costs; logistics costs systems; supply chain; automotive industry; logistics costs data analysis;

\section{INTRODUCTION}

Changes in the understanding and organisation of the supply chain have yielded strong partner relationships for companies involved in the automotive industry, but they also brought new obligations and responsibilities [1]. In an effort to build an efficient supply chain, various customer demands move down the chain and often result in increased logistics costs. These companies have an approach to controlling logistics costs that is based on the experience of employees in a particular area. This can lead to differences in the perception of the important elements in the logistics process of the sale and purchase of goods. The sales department is focused on satisfying customer requirements with smaller batches in terms of quantity, longer payment terms and the assurance of adequate safety stock levels. These types of demands can increase the cost of transport and warehousing, while larger stocks and longer payment terms can negatively affect the company's liquidity. On the other hand, the purchasing department is focused on acquiring large quantities of goods with shorter payment terms, because this is the easiest way to obtain quantity discounts. This will also result in higher warehousing costs, as the company will have to acquire additional warehousing space, as well as in a higher cost of capital in stocks. In addition, the company will face more difficulties in ensuring its liquidity.

Over time, companies have begun optimising the costs of logistics activities by implementing systems for controlling logistics costs. This is because employees tend to have a limited knowledge of logistics [2-4] and generally pursue the goals of their own business areas. Systems for controlling logistic costs that combine the use of different management methods and logistics cost models have been perfected to the point that their use has become the basis for future cost optimisations in companies.

On the other hand, the use of systems for controlling logistics costs can cause disruptions in business processes, due to an excessive focus on cost reduction. Companies that have implemented a system for controlling logistics costs have lower logistics costs than other companies. However, there is no clear evidence of how disruptions in the business processes of these companies are affected by customer demands for business process improvement. The same applies to customer demands to reduce costs in the supply 


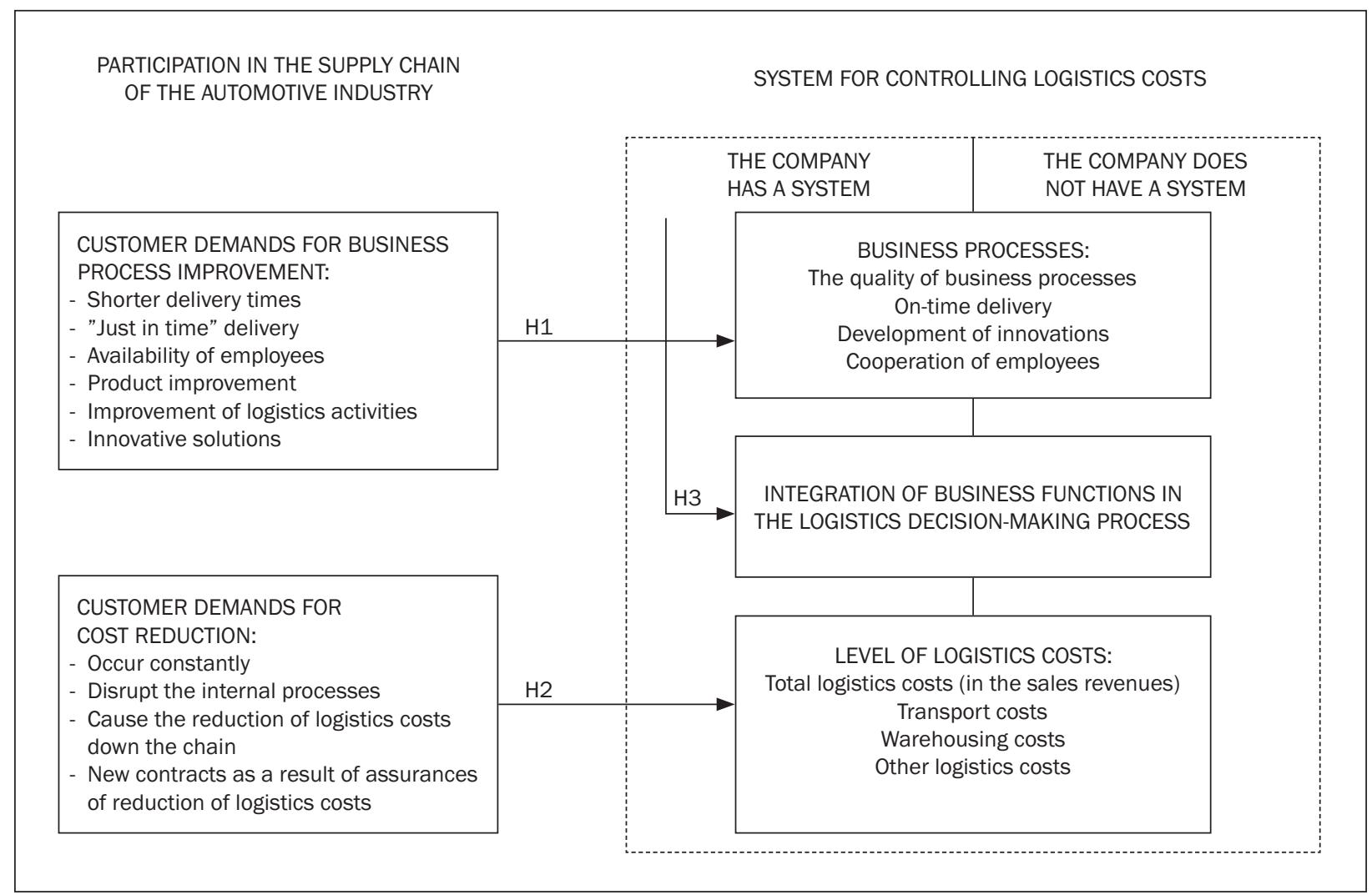

Figure 1 - Research model

chain. Companies that use a system, for example, can have lower logistics costs only by reducing logistics costs down the chain. This can affect long-term relationships in the supply chain, where business partners are regarded solely as an opportunity to reduce costs. For this purpose, a survey was conducted on a sample of 30 Slovenian companies that operate as suppliers in the automotive industry, whose main objective was to determine:

- the impact of different customer demands in the supply chain on the business processes of suppliers and the level of logistics costs;

- the usability of systems for controlling logistics costs in terms of quality assurance and in terms of organising business processes and relationships in the supply chain;

- the current state of logistics costs controlling in the Slovenian automotive industry.

Based on the research objectives, the following research question was addressed: Does participating in the supply chain of the automotive industry require the implementation of a system for controlling logistics costs?

The main research question will be examined through the following hypotheses (Figure 1):

H1: Customer demands for business process improvement in the supply chain of the automotive industry have an impact on business processes of suppliers;
$\mathrm{H} 2$ : Customer demands for cost reduction in the supply chain of the automotive industry have an impact on the level of suppliers' logistics costs;

H3: Using systems for controlling logistics costs enables better integration across business functions in the logistics decision-making process.

The survey presents a thorough analysis of the impact of various customer demands in the supply chain of the automotive industry on the business processes and logistics costs of the suppliers. Thus, the study represents an important contribution for manufacturing companies in Slovenia and the wider region. This will allow companies to become more successful participants in the international automotive industry. The results obtained will represent an important starting point for determining whether the theoretical development of systems for controlling logistics costs reflects the actual needs of companies in the automotive industry. The companies included in the survey sample generate a total of EUR 2.2 billion in annual revenues and collectively employ over 14,000 employees.

\section{REVIEW OF THE LITERATURE RELATED TO CONTROLLING LOGISTICS COSTS}

The first research in the field of controlling logistics costs in companies was conducted by Blumenfeld et al. [5], who reviewed the case of General Motors. The object of the analysis were the deliveries of goods from 
20,000 suppliers to 160 General Motors production plants and the objective was to reduce the total logistics costs. The introduction of the decision tool Transpart resulted in a $26 \%$ reduction in total annual logistics cost. The same system was later used by various other manufacturing companies in the United States.

More recent studies in the field were conducted by Engblom [6] in 2005 and 2008 on 241 manufacturing and trading companies in Finland. Logistics costs were measured as a percentage of a company's sales revenues and divided into six components: transport, warehousing, inventory carrying, administration, packaging, and indirect costs of logistics. The researchers focused on identifying the differences, in terms of logistics costs, between manufacturing and trading companies, export and import oriented enterprises and between large and small enterprises. The study also included an analysis of the changes in the controlling of logistics costs between 2005 and 2008. Ojala et al. [7] conducted a broader study on the state of logistics in the Baltic region. Part of the study was focused on the state of logistics costs controlling in manufacturing companies. Pettersson and Segerstedt [8] conducted a study in order to determine how 30 different companies in ten different industry sectors measure their supply chain costs and compared the results with the model they developed. They found that logistics costs account for the majority of the supply chain cost structure and that there are still a lot of reservations when it comes to controlling logistics costs in companies.

Other authors were more concerned with the implementation of the various systems for controlling logistics costs and have developed two aspects of the scientific study of logistics costs. The first group of authors focused on the development of managerial methods for systemic costs management. The foundations of the modern study of costs were built by Kaplan, Cooper, Atkinson [9] with the Activity-based Costing Method, which several studies on logistics are later based on, and which different authors [10-17] developed for the purpose of controlling costs across the various segments of a company's logistics operations. In a wider study, Ellstrom [18] analysed logistics cost management methods and their usability for purchasing. Costing methods are allocated on the basis of different points of view and application methods. Estampe et al. [19] presented the 16 known methods, which are useful for various companies in the supply chain business process. In the first stage, the authors described the methods, which were then analysed in terms of: decision level (strategic, tactical, and operational decisions), type of flow (physical, informational, and financial flows), level of supply chain maturity, type of benchmarking (internal and external), contextualization (retailer, industry, service, all sectors), quality factors, human capital, and sustainability. The authors pointed out the fact that companies can opt for more than one model/method, which differ based on the method of organization, distribution of responsibility, and maturity level of the supply chain. Based on the correlation between logistics costs and customer services [20], the following methods are known: Customer satisfaction, Customer value added, Total cost analysis, Analysis of profitability and Shareholder value. From the point of view of simplicity and the possibility of implementation in practice, different authors [2123] highlight Total cost analysis, which means identifying ways for reducing the total costs of logistics, including transport costs, warehousing costs, inventory carrying costs, order processing costs and IT system costs, purchasing costs and lot quantity costs, in order to achieve a certain level of customer service. The basic principle of Total cost analysis takes into account the total costs of all logistics activities. Reducing the costs of one logistics activity can lead to an increase in the costs of other logistics activities, which may be ultimately reflected in higher total costs.

The second aspect of the scientific study relates to the development of logistic models. The theoretical structure of the models is designed using different cost and mathematical methods, which is why the designs vary in complexity, purpose and type of use. Blumenfeld et al. [24] have conducted a study that identifies the optimal strategies of delivering goods on a freight network. They analysed the relationship between transport, warehousing and production set-up costs in order to minimize the total costs. A decomposition method was presented to solve problems with few origins and shipment sizes. A similar study was published by Burns et al. [25], which explored the problem of reducing the total costs of inventory and transport from each supplier to a larger number of customers using the structure of the Economic order quantity (EOQ) model. They derived formulas for the inventory and transport costs and determined the optimal trade-off between these costs. The correlation between the costs of inventory and transport costs was also examined by Speranza and Ukovich [26] with the purpose of optimizing costs in the supply of various products. The study mentioned was upgraded by Bartazzi et al. [27] by seeking cost solutions in the supply of products from one source to a number of different destinations, especially when given a fixed set of possible delivery frequencies. Also in this case, the objective is to reduce the total cost of inventory and transport. The authors present different heuristic algorithms and test them on a set of randomly generated problem instances. Bertazzi and Speranza [28] researched scientific papers which present models for the minimization of the sum of inventory and transport costs in logistics networks. The purpose of their work was to set guidelines for the interpretation of different logistics models over time. 
Zhao et al. [29] addressed the problem of determining the optimal ordering quantity and frequency for a supplier-retailer logistic system in which the transport cost as well as the multiple uses of vehicles are considered. Based on the traditional economic order quantity formula, a modified EOQ model is set and an algorithm for the model is presented. The purpose of the model is to reduce the production, inventory and transport costs. Berman and Wang [30] also built a model that represents a good solution and can serve as a guideline for the future planning and implementation of an appropriate distribution network, where the total costs of transport and inventories are the lowest. Madadi et al. [31] formulated a multi-level inventory model that includes transport costs for planning the replenishment of a single commodity. They extend traditional EOQ model in order to minimize the total inventory cost while considering a discrete transport cost, determining the optimal strategy of the warehouse to decide how often to place orders and developed a collective form of ordering by retailers and plan to minimize the inventory cost of the retailers and the warehouse jointly. Robinson [32] developed a "Landed Cost Model," which compares and evaluates geographic regions based on the different costs: labour, logistics, inventory and duties. Wang and Cheng [33] produced a logistics scheduling model, where the objective is to minimize the sum of work-in-process inventory cost and transport cost, which includes both supply and delivery costs. They proved that if work orders from a supplier, manufacturer and purchaser require the same amount of time to be processed, the costs of inventory and transport can be optimized on all levels. Sajadieh et al. [34] used the model developed to show the importance of coordination and cooperation between the seller and the buyer in a two-stage supply chain. This relationship allows for the costs of inventory and warehousing to be kept at a minimum.

\section{DATA AND METHODS}

The 30 companies that participated in the survey generate a total of EUR 2.2 billion in annual revenues (of which over 80 percent are exports) and collectively employ over 14,000 employees. A two-part online questionnaire was developed for the purpose of the survey. The first part of the questionnaire consisted of four general questions about the company. The second part of the online questionnaire consisted of twenty questions relating to the understanding of the concept of controlling logistics costs, the reasons why companies have or do not have systems in place for controlling logistics costs, the percentage of individual logistics costs in sales revenues, the organization of logistics processes within the company and the demands of customers in the automotive industry. The questionnaire was initially reviewed by four experts in the field: the Head of Logistics in a company with 7,000 employees, the Head of Logistics in a small company with 50 employees and two Heads of Purchasing and Sales in a company with 200 employees. The experts' suggestions and comments were also included in the questionnaire.

The survey was conducted from February 2, 2015 to May 3, 2015. An online questionnaire was sent to the management of each company, following an invitation (in writing and by telephone) to take part in the survey. In total, 40 companies operating in the Slovenian automotive industry were asked to take part in the survey and 10 companies opted not to participate. Most of the individuals who completed the questionnaires were Heads of Logistics. The respondents were contacted in advance to answer any questions they might have, regarding the filling out of the questionnaire.

Linear regression analysis was used to test whether customer demands for business process improvement in the supply chain of automotive companies influence the business processes in companies. Customer demands were measured on a 5-point scale by six Likert-type items and a composite score (average) was computed. The measurement of customer demands showed good validity, as assessed by factor analysis (all items loaded on a single factor with weights $>0.40$ ) and high reliability (Cronbach $\alpha=$ 0.82 . The composite variable was used as an independent variable in the regression model. Business processes were measured by five 5-point Likert-type items, all loading considerably on single factor as assessed by factor analysis and showing high reliability (Cronbach $\alpha=0.81$ ). A composite score as an average on five items was computed and used as a dependent variable in the regression model.

Spearman's correlation coefficient was used to test the correlation between business processes, customer demands for cost reduction and logistic costs. Customer demands for cost reduction were measured on a 5-point scale by five Likert-type items and a composite score (average) was computed. Measurements showed appropriate validity and reliability (Cronbach $\alpha=0.82$ ).

The level of integration of business functions was measured by five 5-point Likert-type items. All loaded on a single factor as evaluated by the factor analysis exhibiting good reliability of measurement (Cronbach $\alpha=0.71$ ). The composite score was calculated (average) and used in further statistical analysis. A T-test was used to evaluate whether companies with and without the system for controlling logistics costs differ in the integration of business functions. ANOVA with Tukey post-hoc tests was used to determine the differences in the integration of business functions between companies, according to their reasons for (non)implementation of the system for controlling logistics costs. 
Groups of companies were formed using hierarchical cluster analysis with $\mathrm{x} 2$ distance and Ward method on ranked reasons for using or not using a system for controlling logistics costs. P-value $<0.05$, two-sided, was considered statistically significant. Statistical analysis was performed in IBM SPSS 22.0.

\section{RESULTS ANALYSIS}

The sample included 2 (6.7\%) enterprises with 11 to 50 employees, 13 (43.3\%) companies with 51 to 250 employees and 15 (50.0\%) companies with more than 250 employees. Of these companies, 19 (63.3\%) have a centralized logistics in a separate department, 10 (33.3\%) have a decentralized logistics and one company has a partially centralized and partially decentralized logistics. Based on this data, a conclusion can be drawn that most companies are aware of the importance of managing the logistics process, since most of them have adopted a centralized logistics organization. The majority of the authors [20-23] define controlling logistics costs as the optimum ratio between the quality of customer service and the logistic costs of the company. This understanding of the concept is shared by the majority of the companies in the surveyed sample (86.7\%).

\subsection{Usage of the System for Controlling Logistics Costs (SCLC)}

In the survey sample, 19 companies (63.3\%) have a system for controlling logistics costs in place, company-wide, while 11 (36.7\%) companies do not have such a system in place. The sampled data (Figure 2) revealed that the main reason for the absence of an SCLC is the practice of controlling logistics costs separately for each department. The second most common reason is the financial investment required for the development of such system, followed by the lack of knowledge and experience. The least common and least important reason is the lack of awareness of the importance of controlling logistics costs. The respondents had different opinions on which of the reasons for having implemented an SCLC are the most important (Figure 2). Most of the respondents agreed that controlling logistics costs is extremely important for the company and that it also gives them greater control over the work processes. Customer demands and the impact of logistics costs on the product price were considered less important reasons for having implemented a system for controlling logistics costs.

Hierarchical clustering resulted in two cohesive groups of companies by their evaluation of the importance of the reasons for not having implemented an SCLC. The first group consists of six companies and the other one of five. The characteristics of the two groups are shown on the right hand side in Figure 2.
The first group includes companies that ascribe little importance (irrelevance) to controlling logistics costs and that lack knowledge and experience in this field. The second group includes companies that manage their logistics costs separately by each department and for which implementing an SCLC would be too costly.

The clustering of reasons for having implemented an SCLC by their importance resulted in four cohesive groups (left hand-side of Figure 2). The first group ascribes the highest importance to the impact on the product prices (median value of importance of price as reason for system implementation is equal to 1 ), the second group reports that increased control over the work processes is the most important (median value of control is equal to 1 ), the third group ascribes the highest importance to customer requirements as well as to logistics costs controlling (median values for both reasons are equal to 2), while the last group ascribes the highest importance to controlling logistics costs (median value for this reason is equal to 1 ).

The results of testing the first hypothesis $(\mathrm{H} 1)$ or whether customer demands for business process improvement in the supply chain of the automotive industry have an impact on business processes of suppliers are shown in Table 1. Customer demands for business process improvement are not statistically significantly associated with business processes in companies operating in the automotive industry $(p>0.05)$

Table 1 - Regression coefficients (and p-values) for simple linear regression predicting business process evaluation in an automotive company.

\begin{tabular}{||c|c|c|c||}
\hline \hline & $\begin{array}{c}\text { Regression } \\
\text { coefficient }\end{array}$ & $t$ & $p$ \\
\hline \hline Constant & 3.75 & 5.34 & $<0.001$ \\
\hline $\begin{array}{c}\text { Customer demands } \\
\text { for business process } \\
\text { improvement }\end{array}$ & 0.08 & 0.46 & 0.647 \\
\hline
\end{tabular}

The hypothesis is tested further by multiple linear regression including the existence of an SCLC in the company and the interaction between former variable and customer demands as control variables in the model. Variable measuring customer demands was centred around the mean to avoid multicollinearity and the interaction between the centred variable and the existence of an SCLC was computed. Results show a statistically significant impact of the interaction on the business processes in the company (Table 2). The association between customer demands and the company's business processes is therefore moderated by the existence of an SCLC in the company. The impact of customer demands on the business processes in companies with an existing SCLC is negative, while it is positive in companies that do not have a system for 


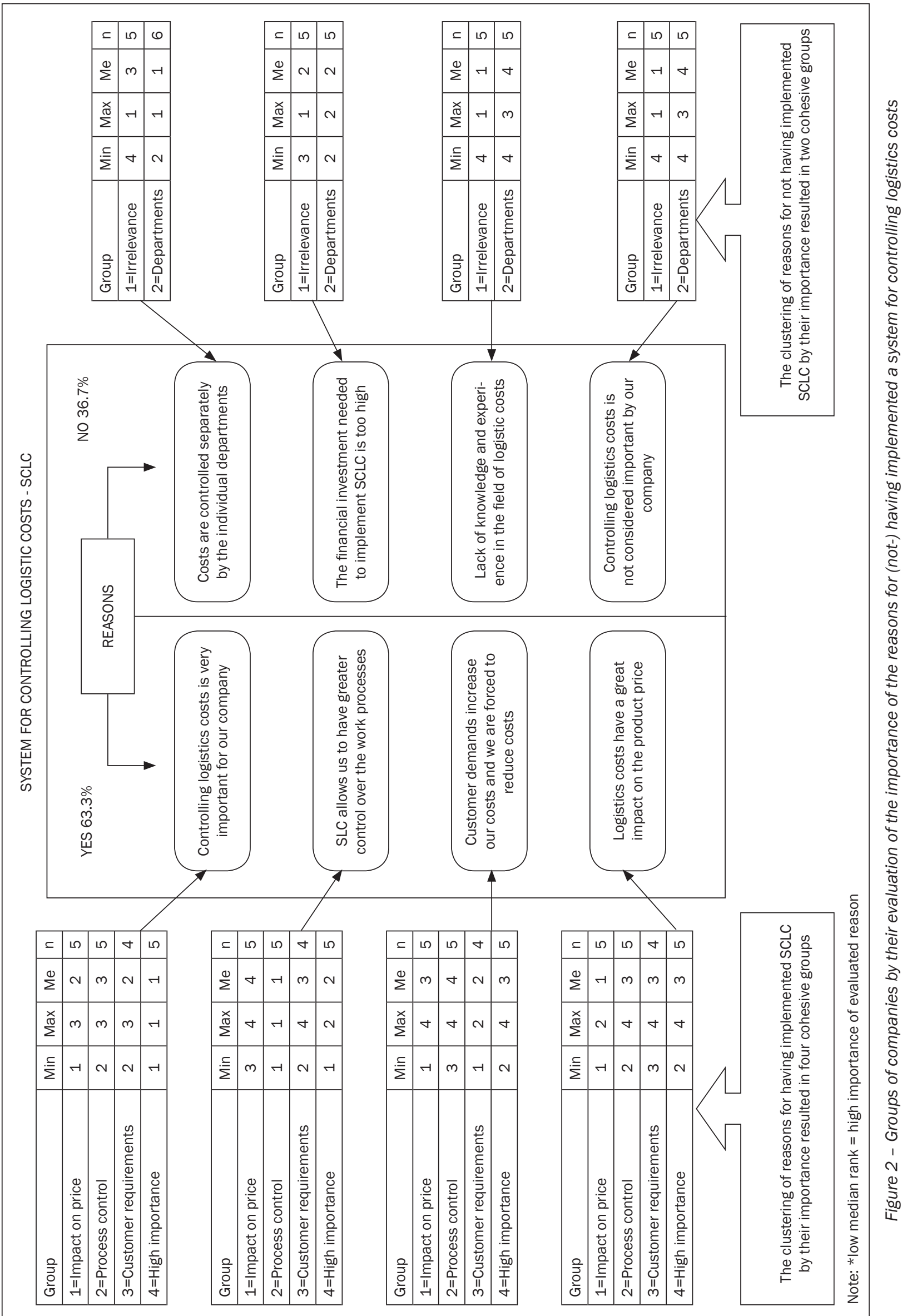


controlling logistics costs. The moderation effect is illustrated in Figure 3.

Table 2 - Regression coefficients (and p-values) for multiple linear regression predicting business process evaluation in an automotive company

\begin{tabular}{||l|c|c|c||}
\hline & $\begin{array}{c}\text { Regression } \\
\text { coefficient }\end{array}$ & $t$ & $p$ \\
\hline \hline Constant & 3.86 & 23.82 & $<0.001$ \\
\hline $\begin{array}{l}\text { System for controlling } \\
\text { logistic costs (SCLC) } \\
\text { yes }\end{array}$ & 0.32 & 1.60 & 0.123 \\
\hline $\begin{array}{l}\text { Customer demands } \\
\text { for business process } \\
\text { improvement (centred) }\end{array}$ & 0.47 & 2.22 & 0.036 \\
\hline $\begin{array}{l}\text { SCLC x Customer } \\
\text { Demands }\end{array}$ & -0.82 & -2.61 & 0.015 \\
\hline
\end{tabular}

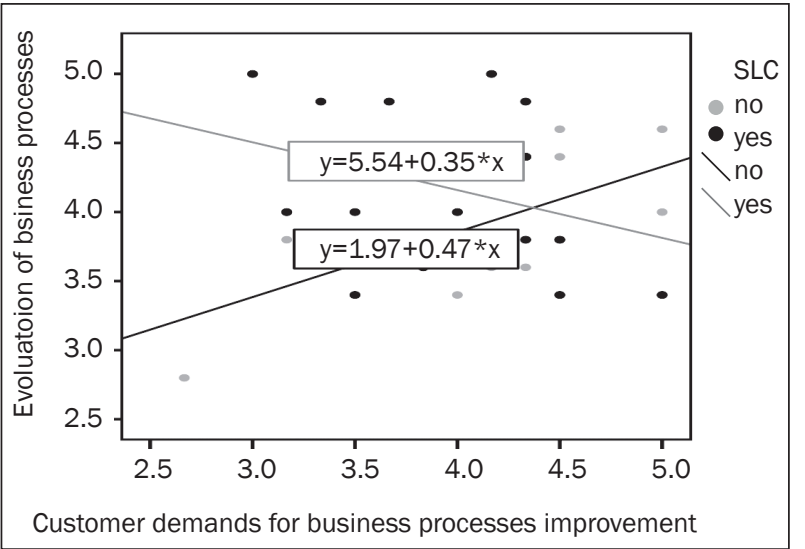

Figure 3 - The moderating effect of an existent system for logistics control on the association between customer demands for business process improvement and the company's business processes
The next hypothesis $(\mathrm{H} 2)$ consists of determining whether customer demands for reducing costs in the supply chain of the automotive industry have an impact on the level of logistics costs of suppliers. The association is moderated by the presence of the SCLC. In companies that do not have a system for controlling logistics costs, customer demands to reduce costs have a statistically significant positive correlation with the level of logistics costs in sales revenues $(r=0.87 ; p=$ 0.001 ), but not with individual logistics costs ( $p>0.05$ ). In companies that do have a system of controlling logistics costs, there is no statistically significant correlation between customer demands for the reduction of costs and the level of logistics costs (Figure 4)

Further analysis of the correlation (Table 3) shows that, in the case of companies that do not have a system for controlling logistics costs, constant demands for cost reduction is associated with lower transport costs $(r=-0.69 ; p=0.038)$. In these companies, demands for reducing costs result in a reduction in logistics costs to suppliers, which is associated with higher logistics costs in sales revenue ( $r=0.82 ; p=0.004)$. In these companies, new contracts awarded solely on the basis of an assurance of cost reduction are associated with higher logistics costs in sales revenue $(r=$ $0.68 ; p=0.032$ ). A statistically marginally significant correlation in companies without systems for controlling logistics costs was found, between customer demands causing disruptions in the internal processes of the company and logistics costs in sales revenues $(r=0.60 ; p=0.064)$ as well as other logistics costs in the logistics costs structure $(r=0.59 ; p=0.097)$.

The last hypothesis (H3) consists in determining whether the use of systems for controlling logistics costs enables better integration across business

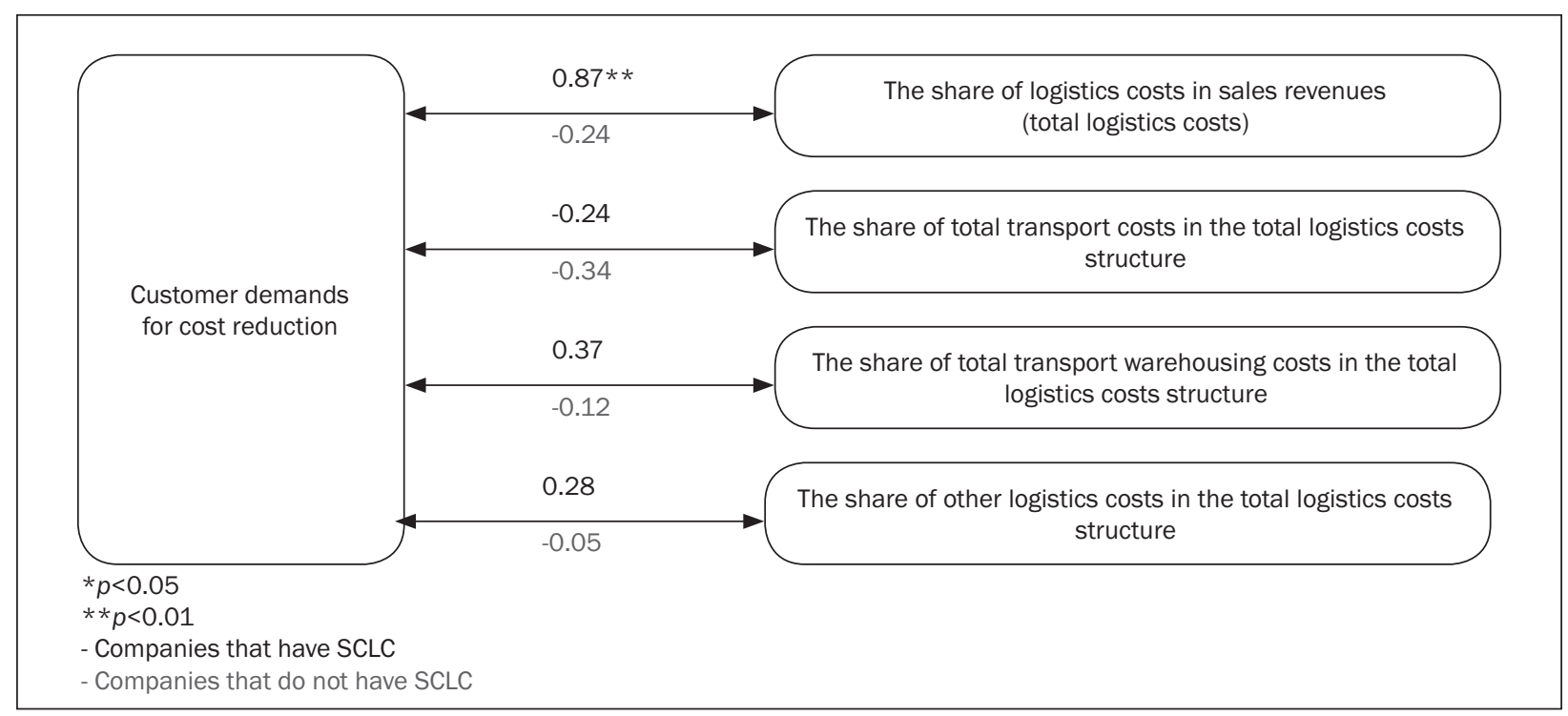

Figure 4 - Spearman's correlation coefficient between customer demands for reducing costs and the level of logistics costs in relation to the presence of a system for controlling logistics costs 
Table 3 - Spearman's correlation coefficient between individual customer demands for reducing costs and the level of logistics costs in relation to the presence of a system for controlling logistics costs

\begin{tabular}{||l|c|c|c|c|c||}
\hline & SCLC & $\begin{array}{c}\text { The share of } \\
\text { logistics costs in } \\
\text { sales revenues }\end{array}$ & $\begin{array}{c}\text { The share of } \\
\text { transport costs in } \\
\text { the total logistis } \\
\text { costs structure }\end{array}$ & $\begin{array}{c}\text { The hare of ware- } \\
\text { housing costs in } \\
\text { the total logistics } \\
\text { costs structure }\end{array}$ & $\begin{array}{c}\text { The share of other } \\
\text { logistics costs in } \\
\text { the total logistics } \\
\text { costs structure }\end{array}$ \\
\hline \hline \multirow{2}{*}{$\begin{array}{l}\text { Constant demands for cost } \\
\text { reduction }\end{array}$} & no & 0.47 & $-0.69 *$ & 0.29 & -0.37 \\
\cline { 2 - 6 } & yes & -0.23 & -0.01 & 0.38 & -0.07 \\
\hline $\begin{array}{l}\text { Demands for cost reduction } \\
\text { causing disruptions in the } \\
\text { internal processes }\end{array}$ & no & $0.60^{\wedge}$ & 0.10 & 0.37 & $0.59^{\wedge}$ \\
\hline & yes & -0.11 & -0.42 & -0.22 & 0.19 \\
\hline $\begin{array}{l}\text { Demands for reducing costs } \\
\text { results in a reduction in logis- } \\
\text { tics costs to suppliers }\end{array}$ & no & $0.82^{* *}$ & -0.30 & 0.33 & 0.36 \\
\cline { 2 - 6 } & yes & 0.12 & -0.17 & -0.28 & -0.27 \\
\hline \multirow{2}{*}{$\begin{array}{l}\text { New contracts awarded solely } \\
\text { on the basis of an assurance } \\
\text { of cost reduction }\end{array}$} & no & $0.68 *$ & -0.09 & 0.11 & 0.28 \\
\cline { 2 - 6 } & yes & -0.38 & -0.05 & -0.04 & -0.10 \\
\hline
\end{tabular}

functions in the logistics decision-making process. The hypothesis was tested using a t-test and the results are shown in Table 4. No statistically significantly higher integration in the process of logistic decision-making can be found among companies with an existent SCLC in comparison to companies without an SCLC.

The hypothesis was tested further by investigating the difference in the integration of the process of logistic decision-making between the groups of companies, according to their primary reason for the (non-) existence of an SCLC. As shown in Figure 1, companies can be divided into six groups, based on their primary reason for the (non-) existence of an SCLC. An analysis of variance showed statistically significant differences in the integration of the process of logistic decision-making between the groups of companies $(F(5 ; 23)=2.79 ; p=0.041)$. Further examination of the differences was carried out with Tukey's post-hoc test. Statistically significant difference was found between companies with SCLC enabling them greater process control and companies without SCLC perceiving SCLC as irrelevant (difference in means $=1.2 ; p=$ 0.026). The first group shows better integration of their business functions into the logistics decision-making process than the second group (Table 5). From this point of view, the hypothesis can be partly accepted.

Table 4 - Assessing the difference in the integration of the process of logistic decision making between companies, according to whether they have a SCLC or not (results of the t-test)

\begin{tabular}{|c|c|c|c|c|c|c|c|c|}
\hline \multirow[t]{2}{*}{ SCLC } & \multicolumn{5}{|c|}{$\begin{array}{c}\text { The integration } \\
\text { of the logistics decision-making process }\end{array}$} & \multicolumn{3}{|c|}{$t$ - test } \\
\hline & Min & Max & AS Mean & SD & $\mathrm{n}$ & $\mathrm{t}$ & $\mathrm{df}$ & $\mathrm{p}$-value \\
\hline no & 2.40 & 4.20 & 3.24 & 0.55 & 10 & \multirow{2}{*}{-1.2} & \multirow{2}{*}{27} & \multirow{2}{*}{0.113} \\
\hline yes & 2.40 & 4.80 & 3.54 & 0.64 & 19 & & & \\
\hline
\end{tabular}

Table 5 - The integration of the logistics decision-making process

\begin{tabular}{|c|c|c|c|c|c|c|c|c|c|}
\hline \multirow{2}{*}{$\begin{array}{l}\text { Groups of companies ac- } \\
\text { cording their reasons for the } \\
\text { (non-) existence of a SCLC }\end{array}$} & \multicolumn{5}{|c|}{$\begin{array}{l}\text { The integration } \\
\text { of the logistics decision-making process }\end{array}$} & \multicolumn{4}{|c|}{$\begin{array}{l}\text { The result of the } \\
\text { analysis of variance }\end{array}$} \\
\hline & Min & Max & $\begin{array}{c}\text { AS } \\
\text { Mean }\end{array}$ & SD & $\mathrm{n}$ & $\mathrm{t}$ & DF1 & DF2 & $\mathrm{p}$-value \\
\hline YES, impact on price & 2.80 & 4.20 & 3.40 & 0.55 & 5 & \multirow{6}{*}{2.8} & \multirow{6}{*}{5} & \multirow{6}{*}{23} & \multirow{6}{*}{0.041} \\
\hline YES, process control & 3.80 & 4.80 & 4.20 & 0.40 & 5 & & & & \\
\hline $\begin{array}{l}\text { YES, customer require- } \\
\text { ments }\end{array}$ & 3.00 & 3.60 & 3.20 & 0.28 & 4 & & & & \\
\hline YES, high importance & 2.40 & 4.40 & 3.28 & 0.76 & 5 & & & & \\
\hline NO, irrelevance & 2.40 & 3.80 & 3.04 & 0.57 & 5 & & & & \\
\hline NO, departments & 3.00 & 4.20 & 3.44 & 0.50 & 5 & & & & \\
\hline
\end{tabular}




\section{DISCUSSION}

The results of the survey show that the companies that took part are well organised in terms of logistics management. Most of them deal with logistics using a centralised approach and have a separate logistics department. Logistics costs represent less than $5 \%$ of sales revenues in most of the surveyed companies. This is a smaller percentage than the one published in a comparable study by Ojala et al. (2007), which analysed the state of logistics costs controlling in manufacturing companies.

Customer demands for business process improvement in the supply chain of the automotive industry have an impact on the business processes of companies that do not have a system for controlling logistics costs (SCLC). Companies that have a system in place are not affected by customer demands, because having an SCLC results in their business processes being less subject to disruptions. Thus, hypothesis $\mathrm{H} 1$ is partly confirmed. This finding is important for answering the main research question, as it demonstrates that companies that use an SCLC are better able to cope with customer demands for business process improvement.

Customer demands for cost reduction in the supply chain of the automotive industry affect companies that do not have a system for controlling logistics costs. These companies have higher total logistics costs. This hypothesis $\mathrm{H} 2$ has therefore also been partially confirmed. The detailed analysis of the results shows a number of findings that are relevant for companies operating in the automotive industry:

- In companies that do not have an SCLC, constant demands for reducing costs are reflected in lower transport costs. Their efforts are focused on one segment of logistics costs, which represent the majority of the costs in the logistics costs structure. However, in doing so, they neglect all other logistics costs. The partial and unbalanced treatment of logistics costs leads to higher total logistics cost in the company, which affects negatively the company's business results.

- In these companies, customer demands for cost reduction result in companies that regard suppliers merely as an opportunity to reduce logistics costs. Companies therefore fail to optimise logistics costs in internal business processes. This may also have a negative effect on the quality of the supplier's logistic services. This is why these companies have higher total logistics costs.

- Companies that do not have an SCLC felt that they were also being regarded by customers as an opportunity to reduce costs. In these companies, new contracts are awarded solely on the basis of an assurance of cost reduction, which is associated with higher total logistics costs.
- Companies that do not use SCLC experience disruptions in their internal business processes, due to customer demands for costs reduction. Because of the lower quality of the processes, companies have higher total logistics costs in sales revenues as well as other logistics costs that are part of the logistics costs structure (inventory costs, IT system costs, etc.).

The third hypothesis was tested in order to determine whether the use of systems for controlling logistics costs enables better integration across business functions in the logistics decision-making process. The results showed that companies that strive for greater control over work processes and use an SCLC have better integration across business functions in the logistics decision-making process. By contrast, the companies that attach little importance to controlling logistics costs and do not use a system for this purpose, showed less integration across business functions. From this perspective, hypothesis $\mathrm{H} 3$ was partially confirmed, since the use of SCLC enables better integration across business functions in the logistics decision-making process only in those companies that recognise the importance of controlling work processes. This may also be due to the fact that the knowledge transmitted with the development of differently structured logistics cost models is more accessible to a small group of logistics experts and less accessible to employees in other business functions.

Figure 5 shows that the relationship between customer demands for business process improvement and business processes in the company is moderated by the existence of an SCLC. Likewise, the relationship between customer demands for cost reduction and the level of logistics costs is moderated by the existence of an SCLC. In addition, the relationship between the existence of an SCLC and the integration of business functions is moderated by the reasons for the (non) existence of an SCLC.

The research results provide an answer to the main research question and confirm that the use of systems for controlling logistics costs in the supply chain of the automotive industry is justified and necessary. The survey presents a thorough analysis of the impact of customer demands in the supply chain of the automotive industry on the business processes and logistics costs of the suppliers. Thus, the study represents an important contribution for manufacturing companies in Slovenia and the wider region. This will allow companies to become more successful participants in the supply chain of the automotive industry.

The results show the effects on quality assurance of business processes, since the use of SCLC causes fewer disruptions in the internal processes in sales, purchasing, manufacturing and logistics. Business functions are more integrated in the logistics 


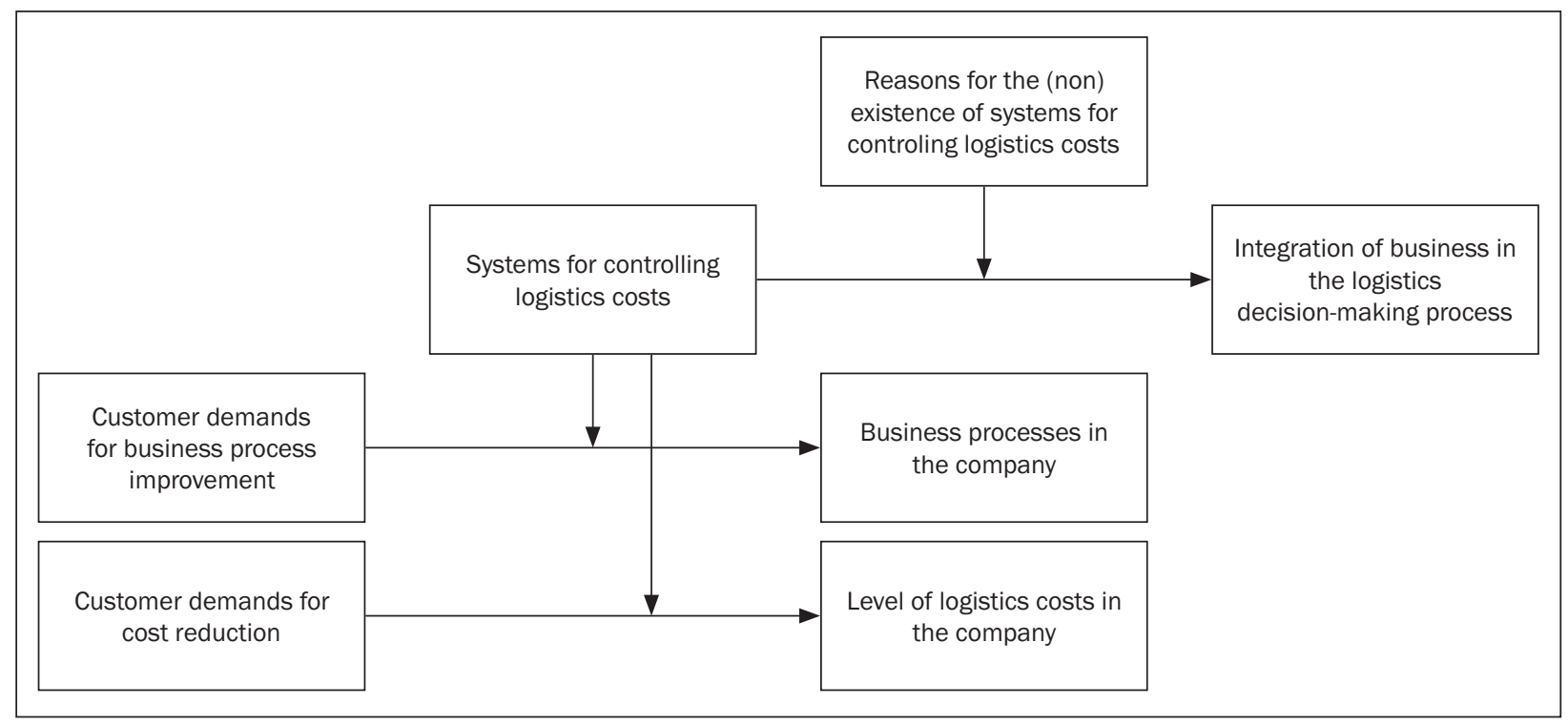

Figure 5 - Model of research findings

decision-making process, particularly when companies want to have more control over work processes.

The survey results show the impact on long-term relationships with suppliers in the supply chain. Companies that do not use an SCLC are more focused on reducing logistics costs to suppliers and can thus neglect other aspects of cooperation and partnership in the supply chain.

The study has a significant relevance for the controlling of transport logistics in the Slovenian automotive industry. Despite the fact that the use of systems for controlling logistics costs is the basis for the future optimisation of costs, $37.6 \%$ of the companies surveyed do not use such a system. Thus, Slovenian companies have not been able to benefit from all the possibilities offered by the use of such systems. In time, this can put them at a disadvantage against their competitors in the demanding sector of the automotive industry in the medium term.

\section{CONCLUSION}

The survey conducted represents one of the first contributions to include an analysis of the effects of various customers' demands in the supply chain of the automotive industry on the suppliers' business processes. Based on this, it was possible to determine the impact of the use of SCLC on the quality, costs and organisation of business processes.

It was determined that the use of SCLC is not merely a basis for the future optimisation of costs in companies. Companies that use an SCLC experience fewer disruptions, have higher quality business processes and a different attitude towards the participants in the supply chain. Despite the fact that companies are geared towards a systematic reduction of logistics costs, they do not view their suppliers as an opportunity to reduce logistics costs. The use of SCLC also enables better cooperation between business functions, especially for those companies that recognise the importance of controlling work processes. These findings provide an answer to the main research question and establish clear guidelines for future participation of suppliers in the supply chain of the international automotive industry.

The study therefore has a significant relevance for the controlling of transport logistics in the Slovenian automotive industry. Companies that are currently not using a system for controlling logistics costs and that fail to take into account these findings, might find it difficult to participate in the supply chain of the automotive industry in the medium term. Almost $40 \%$ of the companies in the research sample belonged to the aforementioned group. The lack of scientific studies that would provide such results highlights the usefulness of the scientific contribution for the development of the existing systems for controlling logistics costs in theory and in practice.

The analysed research sample comprised a significant number of companies operating in the Slovenian automotive industry and Slovenian companies have a long tradition of participating in the international automotive industry. However, the number of companies in the Slovenian automotive industry is relatively low. In the future, it would be sensible to carry out a similar study in comparable countries (e.g. the Czech Republic or Slovakia) and compare the results. Germany, as the country that ranks highest in terms of development of the automotive industry, represents a reference area for further studies of the scientific problem presented in this study. 
Mag. SEBASTJAN ŠKERLIČ́ ${ }^{1}$

E-mail: sebastjan.skerlic@fpp.uni-lj.si

Doc. Dr. ROBERT MUHA ${ }^{1}$

E-mail: robert.muha@fpp.uni-lj.si

${ }^{1}$ Univerza v Ljubljani, Fakulteta za pomorstvo in promet

Pot pomorščakov 4, 6320 Portorož, Slovenija

\section{POMEN SISTEMOV OBVLADOVANJA LOGISTIČNIH STROŠKOV V OSKRBOVALNI VERIGI: ŠTUDIJA PRIME- RA SLOVENSKE AVTOMOBILSKE INDUSTRIJE}

\section{POVZETEK}

Sodelovanje $v$ avtomobilski industriji prinaša dobaviteljem odgovornosti iz vidika upoštevanja zahtev kupcev tako po izboljšavah poslovnih procesov kot nižanja stroškov. Takšne zahteve kupcev lahko povzročijo motnje v podjetjih, kjer nimajo vzpostavljenega sistema obvladovanja logističnih stroškov. V podjetjih, ki imajo takšen sistem pa lahko zahteve povzročijo drugo vrsto motenj, povezanih s preveliko osredotočenostjo k zniževanju stroškov. $V$ ta namen je bila izvedena raziskava na vzorcu 30 slovenskih podjetjih, dobaviteljih svetovni avtomobilski industriji s ciljem ugotoviti vpliv različnih zahtev kupcev $v$ oskrbovalni verigi na poslovne procese dobaviteljev in na višino logističnih stroškov. Raziskava je pokazala, da v podjetjih kjer je vzpostavljen sistem obvladovanja logističnih stroškov zahteve kupcev občutijo z manj motnjami $v$ poslovnih procesih, poslovne funkcije so bolj povezane in podjetja imajo drugačen odnos do udeležencev oskrbovalne verige. Prav tako raziskava postavlja jasne smernice sodelovanja dobaviteljev $v$ oskrbovalni verigi avtomobilske industrije in poudarja pomen uporabe sistemov obvladovanja logističnih stroškov tudi iz drugih vidikov, ne samo stroškovnega.

\section{KLUUČNE BESEDE}

logistični stroški; logistični stroškovni sistemi; oskrbovalna veriga; avtomobilska industrija; podatkovna analiza logističnih stroškov;

\section{REFERENCES}

[1] Bajec P, Jakomin I. A make-or-buy decision process for outsourcing. Promet - Traffic \& Transportation. 2010;22(4):285-291.

[2] Nam-Hong Y, Soung-Hie K, Hee-Woong K, Kee-Young $\mathrm{K}$. Knowledge based decision making on higher level strategic concerns: system dynamics approach. Expert Systems with Applications. 2004;27(1):143-158.

[3] Tokar T, Aloysius J, Waller MA. Supply Chain Inventory Replenishment: The Debiasing Effect of Declarative Knowledge. Decision Sciences Journal. 2012;43(3):525-546.

[4] Bartolacci MR, LeBlanc $\amalg$, Kayikci Y, Grossman TA. Optimization Modeling for Logistics: Options and Implementations. Journal of Business Logistics. 2012;33(2):118-127.

[5] Blumenfeld DE, Burns LD, Daganzo CF, Frick MC, Hall RW. Reducing logistics costs at General Motors. Interfaces. 1987;17(1):26-37.
[6] Engblom J, Solakivi T, Toyli J, Ojala L. Multiple-method analysis of logistics costs. International Journal of Production Economics. 2012;137(1):29-35.

[7] Ojala L, Solakivi T, Hälinen H, Lorentz H, Hoffmann T. Logonbaltic - State of Logistics in the Baltic Sea Region. Survey Results from Eight Countries. LogOn Baltic master reports. Turku: Turku School of Economics, University of Turku; 2007.

[8] Pettersson Al, Segerstedt A. Measuring supply chain cost. International Journal of Production Economics. 2013;143(2):357-363.

[9] Kaplan RS, Cooper R Cost \& effect: using integrated cost systems to drive profitability and performance. Boston (Mass.): Harvard Business School Press, cop.; 1998.

[10] Pohlen TL, LaLonde BJ. Implementing Activity-based Costing $(A B C)$ in logistics. Journal of Business Logistics. 1994;15(2):1-23.

[11] Goldsby TJ, Closs DJ. Using Activity-Based Costing to Re-engineer the Reverse Logistics Channel. International Journal of Physical Distribution \& Logistics Management. 2000;30(6):500-514.

[12] Themido I, Arantes A, Fernandes C, Guedes AP. Logistic Costs Case Study - An ABC Approach. Journal of the Operational Research Society. 2000;51(10): 1148-1157.

[13] Varila M, Seppanen M, Suomala P. Detailed Cost Modelling: A Case Study in Warehouse Logistics. International journal of Physical Distribution \& Logistics Management. 2007;37(3):184-200.

[14] Everaert P, Bruggeman W, Sarens G, Anderson SR, Levant $Y$. Cost modeling in logistics using time-driven ABC: Experiences from a wholesaler. International Journal of Physical Distribution \& Logistics Management. 2008;38(3):172-191.

[15] Fang Y, Ng ST. Applying activity-based costing approach for construction logistics cost analysis. Construction Innovation. 2011;11(3):259-281.

[16] Schulze M, Seuring S, Ewering C. Applying activity-based costing in a supply chain environment. International Journal of Production Economics. 2012;135(2):716-725.

[17] Krajnc J, Logožar K, Korošec B. Activity-Based Management of Logistic Costs in a Manufacturing Company. Promet - Traffic \& Transportation. 2012;24(1):15-24.

[18] Ellström D, Rehme J, Björklund M, Aronsson H. Logistics cost management models and their usability for purchasing. Journal of Modern Accounting and Auditing. 2012;8(7):1066-1073.

[19] Estampe D, Lamouri S, Paris J, Brahim-Djelloul S. A framework for analysing supply chain performance evaluation models. Int. J. Production Economics. 2013;142(2):247-258.

[20] Lambert DM, Burduroglu R. Measuring and Selling the Value of Logistics. International Journal of Logistics Management. 2000;11(1):1-18.

[21] Christopher M. Logistics and supply chain management: creating value-adding networks. 3rd ed. Harlow: Pearson Education Limited; 2005.

[22] Shang Kuo-Chung. The Effects of Logistics Measurement Capability on Performance. Asia Pacific Management Review. 2004;9(4):671-687. 
[23] Stock JR, Lambert DM. Strategic logistics management. 4th ed. Boston [etc.]: McGraw-Hill/Irwin; 2001.

[24] Blumenfeld DE, Burns LD, Diltz JD, Daganzo CF. Analyzing trade-offs between transportation, inventory and production costs on freight networks. Transportation Res. Part B. 1985;19(5):361-380.

[25] Burns LD, Hall RW, Blumenfeld DE, Daganzo CF. Distribution strategies that minimize transportation and inventory costs. Oper. Res. 1985;33(3):469-490.

[26] Speranza MG, Ukovich W. Minimizing transportation and inventory costs for several products on a single link. Oper. Res. 1994;42(5):879-894.

[27] Bertazzi L, Speranza MG, Ukovich W. Minimization of logistics costs with given frequencies. Transportation Research Part B: Methodological. 1997;31(4): 327-340.

[28] Bertazzi L, Speranza MG. Models and algorithms for the minimization of inventory and transportation costs: a survey. Lecture Notes in Economics and Mathematical Systems. 1999;480:137-157.

[29] Zhao QH, Wang SY, Lai KK, Xia GP. Model and algorithm of an inventory problem with the consideration of transportation cost. Computers \& Industrial Engineering. 2004;46(2):389-397.

[30] Berman O, Wang Q. Inbound Logistic Planning: Minimizing Transportation and Inventory Cost. Transportation Science. 2006;40(3):287-299.

[31] Madadi A, Kurz ME, Ashayeri J. Multi-level inventory management decisions with transportation cost consideration. Transportation Research Part E: Logistics and Transportation Review. 2010;46(5):719-734.

[32] Robinson T. Cost Modelling in the Integrated Supply Chain Strategic Decision Process. Massachusetts Institute of Technology. Department of Mechanical Engineering. Sloan School of Management; 2006.

[33] Wang $X$, Cheng TCE. Logistics scheduling to minimize inventory and transport costs. International Journal of Production Economics. 2009;121(1):266-273.

[34] Sajadieh MS, Thorstenson A, Akbari Jokar MR. An integrated vendor-buyer model with stock-dependent demand. Transportation Research Part E: Logistics and Transportation Review. 2010;46(6):963-974. 